\title{
AGRICULTURA FAMILIAR NO BRASIL: uma revisão teórica
}

\section{Luciana Cristina Moura Zangaro}

Professora do Depto. de Ciências Sociais da Universidade Estadual de Londrina.

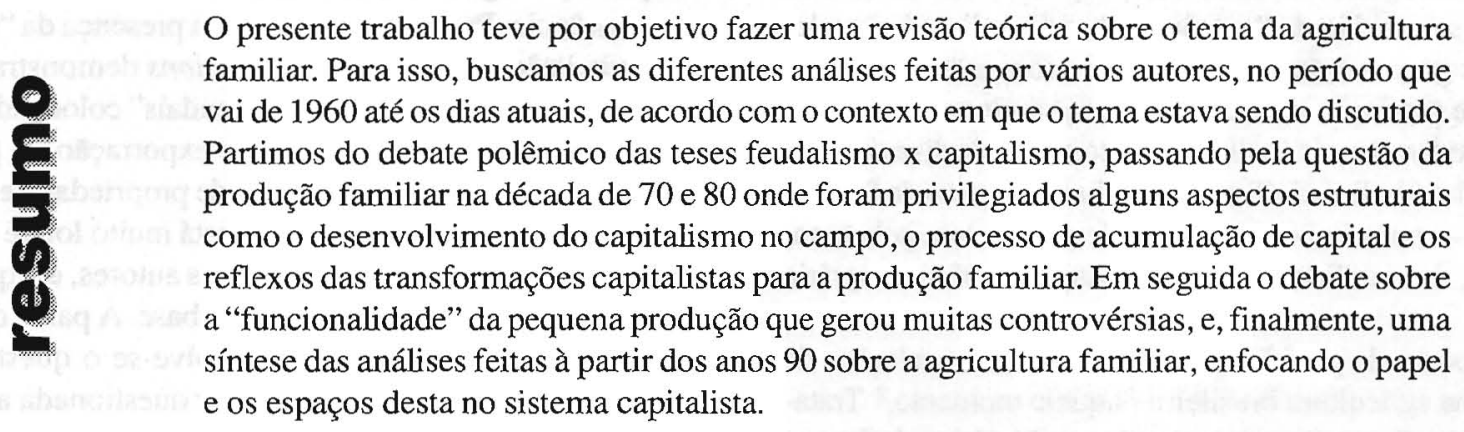

Palavras-chave: campesinato; pequena produção; agricultura familiar; agricultura brasileira; capitalismo.

\section{INTRODUÇÃO}

A agricultura familiar não é uma categoria analítica recente, nem deve ser vista como nova na Sociologia Rural. No entanto, essa categoria tem assumido no Brasil ares de novidades devido ao significado e a abrangência que the tem sido atribuídos nos últimos anos.

As discussões acerca desse tema tem sido direcionado à interrogação das possibilidades e formas de reprodução e transformação da agricultura familiar ${ }^{1}$ nos sistemas socioeconômicos mais amplos em que se inserem.

Dentre as várias questões que se colocam hoje no cenário agrícola brasileiro, a presença da agricultura familiar tem recebido destaque. Primeiro por sua importância qualitativa na agricultura brasileira, como demonstra o trabalho de KAGEYAMA e BERGAMASCO (1989/90), onde, em 1980, dos 5,1 milhões de estabelecimentos rurais, 3,6 (aproximadamente $70 \%$ ) foram classificados como familiares. Segundo por ter sido objeto de uma revalorização e passa a ser vista como uma alternativa para um novo modelo de agricultura, onde o espaço rural seja valorizado do ponto de vista ambiental, econômico e social.

O número de trabalhos que se dedicaram e se dedicam a este tipo de interrogação é tão amplo que não nos propomos aqui a nos referir à todos, mas somente algumas tendências teóricas que o debate vêm tomando no Brasil.

Considerou-se, para os limites da pesquisa, o período entre 1960 até os dias atuais, onde procurou-se fazer uma apresentação das diferentes posições assumidas pelos intelectuais de acordo com contexto de cada período.

Não sendo nossa pretensão - neste trabalho - de abranger todas as análises feitas à respeito da agricultura familiar, o objetivo é mostrar ao leitor os rumos que tomaram os debates desde a década de 60 até os dias atuais. Portanto, o objetivo deste texto é procurar identificar e delinear as principais propostas teóricas elaboradas para conformar a agricultura familiar brasileira, situando tão somente alguns contextos, autores e textos. Desta forma, seria possível sistematizar os rumos do debate, ainda que com muitas ausências, localizando alguns argumentos e questões centrais de um debate que se prolonga até hoje.

\section{A PRODUÇÃO FAMILIAR NO DE- BATE FEUDALISMO X CAPITALISMO}

Pretendemos neste capítulo situar a discussão da produção familiar no debate polêmico das teses "feudalismo $\mathrm{x}$ capitalismo". Não pretendemos aqui sintetizar esse debate, 
tentaremos mostrar um pouco como esse debate foi traçado e o conjunto de questões por onde ele passava, principalmente no que diz respeito à produção familiar. Antes porém, é preciso ter claro que esse debate possui um referencial ideológico que ganhou impulso na década de 60 pela necessidade dos intelectuais de assumir posições diante das lutas políticas do período e, principalmente das divergências dentro da esquerda brasileira.

O debate desenvolveu-se num âmbito mais amplo e é anterior ao período que nos referimos, mas durante os anos 60 ganhou uma certa especificidade devido a dois novos elementos que passaram a fazer parte do debate. De um lado, a emergência do camponês enquanto um protagonista político, nas atuações das nas ligas camponesas e dos sindicatos rurais. De outro, as divisões internas que difundiram-se no interior da esquerda (dentro do PCB e no surgimento de novos partidos). (PALMEIRA, 1984:15). Assim, como cada grupo sentia necessidade de dar a sua própria versão da história brasileira, sua versão da "revolução brasileira", tudo isso levava esses grupos a dar uma resposta sobre a "natureza das relações de produção dominantes na agricultura brasileira". A produção familiar é focalizada no contexto da discussão do complexo latifúndio/minifúndio, tendo como pano de fundo a discussão - num âmbito mais político — da luta pela terra, ou melhor, da viabilidade e oportunidade de reforma agrária no país.

O ponto de partida desse debate eram as relações de produção na agricultura brasileira naquele momento. ${ }^{2}$ Tratava-se de uma discussão sobre o processo histórico da formação da economia agrária brasileira e suas características reais. O debate de idéias sobre a realidade brasileira foi polarizado tanto no plano das análises como das propostas, de um lado em termos de nacionalismo e de outro de um comunismo, onde a primeira opção foi que colocou os termos do debate sobre o desenvolvimento capitalista, durante as décadas de 50 e 60. Partia-se de duas noções, na primeira a agricultura era considerada um setor "atrasado", um obstáculo ao desenvolvimento capitalista devido ao atraso das forças produtivas e a sua incapacidade de produzir alimentos a baixo custo para suprir o mercado interno e também devido a sua estrutura fundiária (latifúndio x minifúndio). De outra perspectiva as relações de produção do campo por não serem capitalistas, retardavam a expansão do mercado consumidor para os produtos industriais. Nos dois casos a transformação do campo era uma condição sine qua non do desenvolvimento capitalista.

A tese "feudalista" refere-se à passagem ou não pelo sistema de relações feudais de produção ou à existência de alguns traços desta no processo econômico brasileiro. Entre os defensores desta tese encontra-se Moisés VINHAS (1972) que argumentava sobre a existência de "traços feudais" no país e que estes tiveram peculiaridades com os de outros países, mas que variam no seu conteúdo e forma em cada cultura e época, nas diferentes regiões do país. Contrapondo-se a essa, Caio PRADO JR. (1966) defensor da tese "capitalista", procura mostrar no seu livro "A Revolução Brasileira" que não ocorreu tal fenômeno, e que não existiram "restos semi-feudais ou pré-capitalistas" nas relações de produção no campo. Segundo PRADO JR., "nada dos senhores de terras se asse- melha aos da Europa pré-capitalista ou da Ásia" (PRADO JR., 1966:107).

$\mathrm{Na}$ análise das relações de produção existentes no Brasil, cria-se uma interrogação em torno do latifúndio, ${ }^{3}$ discutese não só o conceito mas também o conjunto de traços desse latifúndio, onde a resistência à mudança era a mais predominante, para verificar se esses traços se configuram ou não numa realidade capitalista ou feudal, ou seja, se "as técnicas de produção atrasadas utilizadas no latifúndio são feudais ou um tipo de adaptação do capitalismo." Se "o monopólio da terra é capitalista ou ao contrário, é um monopólio entre muitos monopólios." (PALMEIRA, 1984). No caso das relações de produção tem-se a discussão à respeito do assalariado rural, se este é um verdadeiro ou falso assalariado. E a forma de parceria difundida em todo campo brasileiro na época também é questionada, se é falsa ou verdadeira e em que sentido é falsa ou verdadeira. ${ }^{4}$ Outra discussão é sobre a "natureza da exploração agrícola", se é uma unidade de mercado ou de subsistência. Para os "feudalistas", a presença da "agricultura de subsistência" dentro das plantations demonstra a existência de relações "feudais ou semi-feudais" colocando em dúvida a dominância da agricultura de exportação. Já para os defensores da tese capitalista, a grande propriedade exportadora brasileira, nitidamente mercantil está muito longe de ser uma economia natural, que segundo estes autores, é o que caracteriza o feudalismo e que lhe serve de base. A partir desse debate em torno do latifúndio, desenvolve-se o questionamento das classes sociais, onde passa a ser questionada a existência ou não do campesinato no Brasil.

O camponês é identificado pelo grupo da tese "feudalista" tanto quanto pelo grupo da tese "capitalista" como o pequeno produtor que trabalha por conta própria, distinto do proletariado ou do assalariado rural. A diferença entre os dois grupos está na afirmação ou negação da existência desse pequeno produtor camponês no país. Para os primeiros, no Brasil, existe uma "autêntica classe camponesa, que tem a posse efetiva dos meios de produção mas não a sua propriedade jurídica, que se opõe a uma classe latifundiária numa luta pela propriedade da terra". (PALMEIRA, 1984:24). Os autores "feudalistas" analisavam a existência do campesinato ou dos produtores familiares em contraposição ao latifúndio, o relacionamento entre ambos pressupunha relações extra econômicas que foram consideradas como empecilho à penetração do capitalismo no campo. ${ }^{5}$ Os defensores da tese "capitalista" questionam essa afirmação e não concordam com a existência de uma classe camponesa no Brasil. Para esses, existe uma classe de empresários rurais - uma fração da burguesia urbana - possuidores dos meios de produção e muitas vezes proprietários das terras.

Segundo PRADO JR. (1966) no Brasil a população trabalhadora rural não se constituiu em "camponeses" e nem mesmo possuem tradição desse tipo de atividade, os traços culturais desses trabalhadores não dizem respeito a relações e situações socioeconômicas, pois foram absorvidos pela nova ordem social e pela estrutura econômica da qual passaram a participar, ou seja, de uma estrutura econômica onde predominou a grande exploração (a partir da metade do século XIX). Nessa estrutura econômica - grande exploração - o trabalhador se inclui como elemento subordinado e como "simples 
parte de um todo orgânico que é aquela unidade produtora da grande exploração" (p.222).

Para PRADO JR. (1966), o trabalhador rural brasileiro já engajado na estrutura econômica da grande exploração sente-se oprimido e subordinado, e luta por sua liberdade e melhoria das condições de vida, de trabalho, por melhores remunerações e tratamento. Mas não existe por parte desses a possibilidade de passar daí para produtores autônomos pois "exigiria a transformação fundamental da estrutura de produção em que está entrosado, bem como de suas próprias relações e métodos de trabalho"' (p.223). Caio PRADO JR. (1966) não vê uma significação revolucionária na luta pela terra no Brasil, pois faltam aos trabalhadores condições subjetivas e objetivas para reivindicar e lutar pela terra e pela transformação da estrutura agrária no país.

PRADO JR. (1966) nega todo o sentido que os autores da tese feudalista tentam dar à luta pela reforma agrária, pois para ele deve-se lutar pela "transformação da grande exploração com a eliminação de seus aspectos negativos que consistem essencialmente nos baixos padrões tecnológicos, que são a regra, bem como do tipo de relação de trabalho predominantes e que reduzem o trabalhador às miseráveis condições materiais, culturais, sociais que são as suas". (p.227)

Outra colocação feita por PRADO JR. (1966) - defensor da tese capitalista — em relação a pequena produção familiar é que essa não é capaz de substituir a grande exploração, mesmo que haja esse tipo de economia de pequenos produtores e que esses possuam alguma potencialidade de desenvolvimento e extensão, esta não concorre com a grande exploração e não é por ela impedida de se desenvolver e expandir. $\mathrm{O}$ autor nega qualquer funcionalidade da pequena produção.

As críticas feitas aos estudos desse período são principalmente direcionadas ao fato de que tais estudos deixavam entrever uma concepção dual-estruturalista do sistema econômico, onde podia-se ter a visão de uma interdependência entre os setores - agricultura e indústria - mas não visualizava a relação dialética que se estabelece entre agricultura e indústria no processo de acumulação capitalista.

Para alguns críticos a questão das relações sociais de produção na agricultura acabou caindo no argumento de que se essas não fossem formalmente feudais, seriam formalmente capitalistas, obscurecendo assim a visão de uma heterogeneidade de formas de exploração do trabalho no processo de acumulação capitalista da agricultura brasileira. (MARTINS, 1996:11)

\section{OS DEBATES SOBRE A PRODU- ÇÃO FAMILIAR EM 1970 E 1980}

As teses a respeito da formação de um campesinato no Brasil dentro de uma estrutura "feudal" versus a afirmação da empresa capitalista que reduzia todas as formas de relações de produção ao assalariado disfarçado vão sendo superadas à partir da década de 70, quando as discussões tomam novos rumos e o capitalismo passa a ser o elemento explicativo das mais variadas realidades sociais. Os estudos empíricos que foram realizados a partir de então sobre as relações de produção em geral e a pequena produção familiar — em vários contextos regionais do país - tiveram um importante papel para o conhecimento da realidade e a superação daquela polêmica de caráter político e ideológico. As relações de produção na agricultura brasileira passaram a ser analisadas sob o enfoque da acumulação de capital no desenvolvimento do capitalismo no campo e, nesse contexto, o "camponês" começa a ser visto enquanto um produto do capital. Dentre os trabalhos realizados sob esse novo enfoque, muitos tentam mostrar que o capitalismo permite compreender as formas não capitalistas de produção e outros se voltam a mostrar como os pequenos produtores são dominados e explorados no interior do sistema capitalista.

\subsection{A produção familiar como relações de produção não-capitalistas e pré-capitalistas}

A partir da década de 70 foram realizados alguns estudos procurando não ignorar a importância e a especificidade da pequena produção na agricultura brasileira. Os autores daquela época passam a discuti-la através de um ponto comum, no entanto os argumentos correntemente utilizados e os desdobramentos de suas análises são diferentes.

O ponto comum é a afirmação de que a formação social brasileira é capitalista e que é necessário explicar seus elementos a partir da dinâmica do processo de acumulação do capital. (WANDERLEY, 1985:27)

As variações dos argumentos se dão quando se fala na natureza das relações sociais na agricultura. Alguns autores aceitam a explicação teórica de que a natureza das relações sociais na agricultura deve ser vista como o "resultado da reprodução de relações não capitalistas pelo capitalismo dominante". Essa explicação está referenciada nos resultados obtidos numa pesquisa empírica que revela a presença e a importância que as relações não-capitalistas de produção assumem no âmbito da agricultura brasileira, ${ }^{6}$ atestam a suposição de que existe uma "fraqueza" e "incapacidade" por parte do capitalismo na agricultura, por este não ter conseguido realizar a expropriação completa do trabalhador e nem revolucionar o processo de produção de forma ampla e dinâmica. (GRAZIANO DA SILVA, 1980a)

Segundo GRAZIANO DA SILVA (1980a) a debilidade se traduz em quatro pontos: "a) no papel determinante que assume a propriedade da terra; b) na persistência e recriação da pequena produção; c) no fato de não ter conseguido maiores progressos, a não ser em algumas culturas especiais e regiões privilegiadas, e finalmente; d) no alto grau de exploração a que se submete quer a mão-de-obra familiar, quer a mão-deobra assalariada." (GRAZIANO DA SILVA, 1980a:227-234)

Outro autor que também parte da perspectiva de análise que tem como núcleo central a acumulação capitalista é José de Souza MARTINS, mas esse recusa a referência à uma fraqueza ou incapacidade do capital. No trabalho de MARTINS (1996) sobre o sistema de colonato nas fazendas de café, o autor discute a questão das condições de reprodução e de subordinação da estrutura camponesa às formas vigentes do capital. $\mathrm{O}$ autor explicita suas hipóteses de que: 
"a produção capitalista de relações não capitalistas de produção expressa não apenas uma forma de reprodução ampliada do capital, mas também a reprodução ampliada das contradições do capitalismo - o movimento contraditório não só de subordinação de relações pré-capitalistas, mas também de relações antagônicas e subordinadas não-capitalistas. (...)". (MARTINS, 1996:21).

A hipótese de MARTINS (1996) formulada a partir da análise da teoria da renda fundiária de Marx busca uma saída para a problemática de como em determinados ramos da produção agrícola permanece e se reformula um tipo de produção que não é pré-capitalista e nem está organizado segundo os pressupostos característicos do modo de produção capitalista.

A solução encontrada por MARTINS é de realizar uma análise centrada na subordinação da renda da terra ao capital. Segundo o autor, sendo a terra um fator natural, sem valor por não ser resultado do trabalho humano, essa não deveria ter preço. No entanto, antes do advento do capitalismo, nos países europeus, o uso da terra estava sujeito à um tributo, essas eram formas pré-capitalistas de renda decorrentes do fato de que algumas pessoas tinham o monopólio da terra, cuja utilização ficava sujeita a um tributo. No sistema capitalista essa irracionalidade não desaparece, ao contrário a propriedade fundiária foi incorporada ao capitalismo, essa contradição é expressa na renda capitalista da terra. Tal renda não é mais um tributo pessoal do servo ao senhor; agora é um pagamento que toda sociedade faz pelo fato de que uma classe preserva $o$ monopólio da terra. (MARTINS, 1996:20)

Nesses termos, o capital subordina e se apropria sempre da renda da terra, sendo assim, o desenvolvimento da agricultura capitalista é balizado pela sujeição da renda territorial ao capital. Os pequenos produtores, neste contexto, perdem a sua autonomia sobre a propriedade rural, tal perda é efetivada pela apropriação da renda gerada na produção agrícola, beneficiando setores sociais de produção não-rurais.

MARTINS (1996) concebe a permanência e a transformação de formas não capitalistas ${ }^{7}$ como um processo específico de desenvolvimento capitalista, onde o capital "preserva, redefine e subordina" relações pré-capitalistas, engendrando relações não capitalistas.

\subsection{Os reflexos da transformações capitalis- tas nas interpretações sobre a produção fa- miliar:}

A agricultura brasileira teve acelerado seu processo de modernização na década de 70 . No entanto, em termos de regiões e de tipos de produtos/produtores essa continuava sendo parcial e nem afetou globalmente todo o processo produtivo. A alavanca dessa aceleração nesse período foi a política governamental de crédito rural subsidiado, que tornou-se a condição necessária para o processo de modernização da agricultura.

Algumas regiões foram mais beneficiadas do que outras nessa política - a região Centro-Sul muito mais que a região Norte-Nordeste - que relevou os produtos "modernos" reduzindo os custos de produção e paralelamente contribuiu para piorar a rentabilidade dos produtos tradicionais. Essa política - como já foi bastante discutido em vários trabalhos - privilegiou os grandes produtores em detrimento dos pequenos. Segundo alguns autores que estudaram os impactos do processo de modernização, esse significou uma aceleração da concentração fundiária, a proletarização de muitos trabalhadores rurais, o êxodo rural, etc., ${ }^{8}$ que são para esses manifestações típicas do processo de desenvolvimento capitalista no campo.

Não faremos aqui uma revisão das avaliações do impacto da modernização, interessa-nos destacar que a sistematização desses impactos - a que foram submetidas as unidades familiares de produção - foi feitas por vários autores, sendo que o caminho traçado foi em relação à articulação do pequeno produtor com os setores capitalistas, pois a modernização representa para o pequeno produtor muito mais uma imposição do que uma conquista. O sentido amplo dado à modernização é o de que esse a levou a uma maior subordinação do pequeno produtor ao capital, mesmo que o resultado final não tenha sido o mesmo para todos, ou seja, enquanto alguns sofreram um processo de diferenciação - onde poucos se modernizavam -, outros caminhavam em direção a um processo de decomposição ou proletarização, outros ainda seguiram o caminho da capitalização, tudo isso dependendo das particularidades com que foi redefinida sua articulação com o capital.

SORJ (1980) no seu trabalho faz uma síntese das tendências básicas em curso diante desse contexto. Para SORJ (1980), as transformações que ocorrem diante dessa nova realidade do campo - penetração crescente do capital no processo produtivo - levaram a uma "diferenciação constante das características dos diferentes tipos de empresas agrícolas". Ou seja, grande parte dos latifúndios passariam a ser modernas empresas capitalistas diferenciando-se dos latifúndios tradicionais baseados na exploração da renda dos pequenos produtores. Quanto a esses últimos - pequenos produtores - ou se integram às Agroindústrias, criando uma camada de produtores capitalizados, ou aqueles que não se integram acabam se marginalizando. (SORJ, 1980:12)

Podemos afirmar que o processo crescente de penetração do capital na base do processo produtivo agrícola determina uma transformação constante na estrutura de classes do agro brasileiro. Â luz dessas transformações, onde percebe-se uma subordinação da agricultura aos complexos agroindustriais e a outros tipos de capitais, alguns autores fazem uma reinterpretação do desenvolvimento agrícola. Nesse momento passa a existir também um reconhecimento do pequeno produtor capitalizado e o conceito de proletarização passa por uma redefinição onde esse processo se dá quando há separação do produtor direto dos seus meios de produção.

Dentre os trabalhos que vão nessa direção podemos citar o de WANDERLEY (1985), que inspirada em colocações da literatura sociológica européia, propõe que a presença do pequeno produtor/trabalhador rural seja vista como o resultado da eliminação de uma forma particular de produção camponesa e reprodução de um "trabalhador para o capi- 
tal", diferente do proletariado mas assim como este agente e portador de força de trabalho. ${ }^{9}$

A hipótese da autora citada é que a expropriação da força de trabalho não se realiza somente pelo processo de proletarização, onde há uma separação do produtor direto de seus meios de produção, mas sob outras formas, que redefinem o conceito - e a realidade - da propriedade das condições objetivas do trabalho, ou seja, na capacidade do capital de estabelecer o controle direto sobre o processo de produção, onde o controle jurídico e formal permanece com o produtor. (WANDERLEY,1985:38)

Segundo WANDERLEY (1985), uma transformação qualitativa do camponês ocorre quando esse passa a ocupar esse espaço criado pelo próprio capital, o que tornaria inadequados os conceitos de pré ou não capitalista para apreender a realidade das relações sociais a que está submetido o produtor familiar/trabalhador rural.

GRAZIANO DA SUVA (1980b), ${ }^{10}$ assim como a autora citada, também propõe essa redefinição do conceito de proletarização, interpretando-o amplamente como o processo de subordinação direta do trabalho ao capital e não simplesmente como a expropriação completa do camponês dos seus meios de produção. O autor utiliza os conceitos de subordinação real e formal para retrabalhar a idéia de "novo camponês" ou como WANDERLEY (1985), "trabalhador para o capital”. (GRAZIANO DA SILVA, 1980b)

Segundo GRAZIANO DA SILVA (1980b), são trabalhadores para o capital todos aqueles que contribuem para a acumulação do capital, seja na grande lavoura de exportação, seja na agroindústria ou para o capital comercial. Sendo assim, moradores, agregados, colonos, posseiros, meeiros, pequenos arrendatários, sitiantes, etc., seriam todos trabalhadores para o capital, mesmo conservando o acesso à terra.

\subsection{A subordinação do trabalho ao capital e a unidade de produção familiar}

A ênfase no fato de que a reprodução ampliada do capital na agricultura estaria realizando - tanto mediante expropriação do produtor direto quanto através de dominação do capital sobre processos de trabalho - uma reprodução subordinada do campesinato, foi dada em alguns trabalhos a partir do final da década de 70. Dentre os que seguiram essa linha destacamos os de Afranio GARCIA JR. (1983), Otávio Guilherme VELHO (1976) e José Vicente Tavares dos SANTOS (1984).

Em seu trabalho sobre os foreiros da Zona da Mata pernambucana, GARCIA JR. (1983) procurou fazer uma análise da estrutura interna do funcionamento e do movimento da economia da produção baseada no trabalho familiar, analisando a partir das práticas e concepções dos próprios camponeses sobre o seu trabalho e modo de vida o movimento da economia destes pequenos produtores, em particular as determinações do trabalho familiar.

Para o autor, esse tipo de produção apresenta uma especificidade onde a unidade de produção e a de consumo são constituídas por regras de parentesco e pelo caráter familiar do trabalho. Essa especificidade é que justifica a conside- ração do campesinato enquanto um modo de produção subordinado, que pode se articular com vários outros modos de produção, ou que se insere em formações sociais diferenciadas, cujo movimento é dado por outro modo de produção dito dominante. (GARCIA JR., 1983:16)

Também VELHO (1976) considera o campesinato como um modo de produção subordinado. Para este autor, o conceito de subordinação é o elemento central para definir o campesinato. Segundo VELHO, no "capitalismo autoritário" o campesinato não é destruído e nem transformado, mas se mantém subordinado, "continuando a extrair de várias formas um excedente dele ao mesmo tempo que controlando a acumulação da sua própria camada superior. $\mathrm{O}$ campesinato não é destruído, mas é como que "confinado" aos limites de um espaço social dado". (VELHO, 1976)

Seguindo essa linha de pensamento, o trabalho de SANTOS (1984) sobre os produtores de uva no Rio Grande do Sul, integrados às agroindústrias processadoras foi de suma importância. ${ }^{11} \mathrm{~A}$ análise feita pelo autor parte da conceituação de trabalho camponês e da subordinação formal ao capital, e sua tese está baseada na afirmação de que o processo de trabalho do camponês não é destruído pelo capitalismo - assim como VELHO - , e também que o capital exerce um tipo de "subordinação formal"12 do processo de trabalho camponês.

SANTOS (1984) demonstra que o trabalho camponês está subordinado formalmente ao capital, na medida em que o capital estabelece um conjunto de determinações sobre o processo de trabalho camponês, sem chegar a expropriá-lo totalmente. Ou seja, de um lado, o capital subordina o processo de trabalho camponês da forma que ele é, mantendo a singularidade desse camponês: a propriedade da terra e dos meios de produção; a utilização da força de trabalho familiar; o baixo nível de mecanização; a produção direta de meios de vida e a produção simples de mercadorias. De outro, o capital impõe suas determinações ao processo de trabalho camponês à medida que converte a terra em equivalente de mercadoria, coagindo o camponês a comprá-la; transformando as regiões camponesas em viveiro de força de trabalho; levando os camponeses a produzir alimentos e matérias-primas para outros setores, estabelecendo uma produção de valor de troca; efetivando a exploração do valor gerado pelo camponês, provocando aumento da jornada de trabalho da família camponesa; efetuando controle parcial do processo produtivo camponês; induzindo o camponês a uma dependência ao capital financeiro que viabiliza a reposição dos meios de produção; e, finalmente, produzindo a pauperização relativa das famílias camponesas. (SANTOS, 1984:125-133)

Neste caso específico, a subordinação interfere no processo de trabalho do camponês em vários níveis. Ao mesmo tempo o camponês, mantém a autonomia do processo de trabalho, ${ }^{13}$ ficando esse na condição de trabalhador independente mesmo que subordinado formalmente ao capital. Temse na produção camponesa, segundo SANTOS, um processo de trabalho não especificamente capitalista, pois nele não se realizam todas as condições fundamentais da relação social de produção capitalista (...). (SANTOS, 1984:171).

Tratava-se não mais de entender a unidade de trabalho familiar como um modo de produção "camponês" articulado e subordinado ao modo de produção capitalista, mas como $a$ 
reprodução de relações não-capitalistas, subordinadas e articuladas à dominação do capital. ${ }^{14}$ Sobretudo esses estudos tentavam demonstrar a importância da unidade de produção familiar para a agricultura brasileira, inseridas num contexto de evolução dos processos de industrialização e de tecnificação da agricultura, ou seja, do desenvolvimento capitalista.

Esses trabalhos mostravam que a reprodução ampliada do capital na agricultura brasileira se realiza simultaneamente pela expropriação do produtor direto, transformando-o em um trabalhador assalariado, e pela reprodução de relações não-capitalistas resultantes do próprio movimento de expansão do capital. Onde essas relações não-capitalistas seriam o recurso - em determinadas condições históricas - para garantir a expansão do próprio capital.

Nesse período - anos 80 - consolidou-se a tese de que a agricultura brasileira havia atingido um grau de "maturidade", ${ }^{15}$ devido ao processo de integração com os capitais industriais, comerciais e financeiros formando os "Complexos Agroindustriais".

\section{A TESE DA FUNCIONALIDADE DA PEQUENA PRODUÇÃO}

Pode-se dizer que de modo geral, as discussões sobre as relações de produção com base na força de trabalho familiar tentam mostrar que é a dinâmica do capital, e não a dinâmica de transição de um modo de produção para outro, que direciona as transformações da agricultura. ${ }^{16}$

Uma das discussões que tomou conta dos debates sobre o meio ruräl no Brasil era a tese de que a estrutura agrária brasileira representa um simples obstáculo ao desenvolvimento econômico, e que as formas "arcaicas" ou "tradicionais" de produção seriam um "entrave" ao desenvolvimento do capitalismo.

Criou-se assim, um debate a respeito do relacionamento da produção familiar com o processo de acumulação, principalmente devido ao argumento de que a primeira teria um papel relevante no rebaixamento do custo de reprodução da força de trabalho urbana, pelo barateamento da produção de alimentos. Nesse contexto encontra-se a polêmica da "funcionalidade" da unidade de produção familiar.

Assim, ao ressaltar a importância da pequena produção familiar, esses autores procuraram demonstrar algumas vantagens em termos de preço da produção camponesa em relação à produção capitalista. Os preços seriam um fator que garantiria sua funcionalidade na dinâmica da acumulação de capital, isso na medida em que contribuiria para baratear a força de trabalho, reduzindo os custos de atividades não-agrícolas pelo fornecimento de produtos agrícolas - alimentos e matérias-primas - para o setor urbano/industrial com baixos preços. PINSKY (1977) e LOUREIRO (1977)

A teorização da "funcionalidade" da pequena produção parte basicamente de uma crítica ao dualismo estrutural ${ }^{17}$ afirmando a existência de relações funcionais entre as formas de agricultura "atrasada" ou "não-capitalistas" e a acumulação capitalista, ou seja, a idéia de uma complementariedade entre essas duas formas. Parte-se da idéia de que a primeira seria funcional à acumulação de capital tanto na cidade como no campo, na medida em que ela reduziria os custos da força de trabalho e ofereceria alimentos a baixos preços, permitindo maior lucratividade e uma acumulação mais rápida.

OLIVEIRA (1972) num trabalho sobre a economia brasileira, comprova que no caso do Brasil, no período pós30, a expansão do capitalismo dá-se mediante a introdução de relações novas no arcaico e a reprodução de relações arcaicas no novo, o que, conforme ele, seria uma maneira de compatibilizar o processo de acumulação, já que o primeiro movimento acarretaria a liberalização de força de trabalho, a qual iria alimentar a acumulação industrial urbana, enquanto o segundo preservaria o potencial de acumulação voltado exclusivamente para a expansão do próprio novo. Segundo OLIVEIRA, tudo isso porque a manutenção desse tipo de atividade organizada sob moldes não-capitalistas constituir-se-ia em uma forma de sustentação dos setores capitalistas considerados estratégicos e, em última análise, do próprio sistema. (OLIVEIRA, 1972:32)

A perspectiva da funcionalidade sustenta-se, portanto, na suposição de que esse tipo de agricultura "não-capitalista", "atrasada", opera a custos menores que a agricultura capitalista, e mais, supõe que as primeiras tenham um papel de reduzir o custo da reprodução da força de trabalho, na medida que boa parte das necessidades da população da força de trabalho engajada na produção capitalista possam ser supridas por bens e serviços produzidos a custos mínimos na pequena produção mercantil. Assim, ao produzirem a custos menores do que nas empresas capitalistas, as pequenas unidades de produção estariam cumprindo sua função de barateamento dos produtos e, em consequiência, contribuiriam para o rebaixamento dos salários dos trabalhadores engajados na produção capitalista. (OLIVEIRA,1972:31)

Muitas foram as crítica dirigidas à tese da funcionalidade da pequena produção com relação ao capital urbano ou com relação às grandes propriedades agrícolas. Entre os autores que podemos destacar estão: SILVA (1977), ${ }^{18}$ SORJ (1980), ${ }^{19}$ SANDRONI (1980) e DAL ROSSO (1980).

Aqui citaremos apenas dois desses estudos que não concordam com o argumento exposto acima sobre a "funcionalidade" da pequena produção, o de DAL ROSSO et al. (1980) e SANDRONI (1980) que procuram mostrar em seus estudos que a concorrência dos produtos capitalistas é extremamente desfavorável à produção mercantil simples, obrigando-a freqüentemente a rebaixar os preços de seus produtos no mercado.

Segundo DAL ROSSO et al. (1980), na pequena produção, devido à necessidade de maior tempo de trabalho social para produzir qualquer produto, é lógico que esse produto de tipo artesanal deveria possuir um valor de troca mais elevado que o de tipo capitalista. No entanto, isso não ocorre porque os produtos da agricultura artesanal não provêm de uma alta produtividade do trabalho, mas de uma sub-remuneração do trabalho, sendo assim não é traduzido na forma de valor. Isso por sua vez não faz com que os preços dos produtos artesanais cheguem mais baixos ao mercado do setor urbano. Ao contrário, a cadeia de exploração do capital comercial sobre os pequenos produtores é que se apropria de boa parte do excedente gerado. 
SANDRONI (1980) critica a tese da "funcionalidade" orientado por razões históricas, teóricas e empíricas. Para SANDRONI, as interpretações sobre a natureza da articulação entre as duas formas - a capitalista e a não capitalista, negando a separação no desenvolvimento das mesmas (característica da concepção dualista), não são satisfatórias, e equivocadas em alguns pontos. Do ponto de vista histórico, o autor argumenta que a "pequena produção mercantil antecede a produção propriamente capitalista, e não a substitui no abastecimento do mercado interno de gêneros alimentícios e algumas matérias-primas. Portanto, não se pode comparar o desempenho de uma produção que já estava constituída (camponesa) com uma forma que ainda não se constituiu ou apenas começa a fazê-lo, como a capitalista. (SANDRONI, 1980: 46) (grifos do autor).

Se a produção camponesa coexistisse com a produção capitalista, essa última não teria condições de competir com a primeira, pois seria responsável pelos preços mais elevados, mas se a produção capitalista oferecesse preços mais baixos esta logo "desalojaria" a produção camponesa, barateando o preço para o consumidor final. Para SANDRONI (1980), se de fato a pequena produção mercantil opera com custos mais baixos e com uma rentabilidade maior que a produção capitalista - argumento utilizado pelos adeptos da tese da funcionalidade - como se explica o fato da produção capitalista tenha se constituído nesse tipo de produção? E como se explica que esta última venha desalojando continuamente ( $\mathrm{em}$ bora não de forma linear) a pequena produção mercantil e aparentemente vencendo a competição entre as duas? (SANDRONI, 1980:47).

Do ponto de vista teórico, SANDRONI (1980) discorda da tese da "funcionalidade" da pequena produção através de preços de seus produtos - assim como DAL ROSSO et al. - , pois de um lado os preços agrícolas devem ser vistos da ótica do lucro - quando referido à empresas capitalistas — e da ótica do valor, quando referidos à pequena produção familiar; de outro lado a importância do capital comercial na formação dos preços agrícolas deve ser considerada. SANDRONI (1980) questiona que se existisse uma funcionalidade da pequena produção mercantil ao capital produtivo, existiriam políticas agrárias de amparo ou pelo menos de manutenção à esses produtores, o que não ocorre no Brasil.

Outra crítica feita por SANDRONI (1980) aos defensores da tese da "funcionalidade", mais especificamente a OLIVEIRA (1972) e MARTINS (1975) foi do ponto de vista empírico. Primeiro SANDRONI (1980) destaca o trabalho de MARTINS (1975), onde esse último vale-se do estudo de caso sobre a pequena produção na Mantiqueira Paulista em contraste com os empreendimentos capitalistas do Vale do Paraiba, onde MARTINS (1975) afirma ter verificado a contabilidade das fazendas produtoras de leite do Vale e confirma a existência de rendimentos líquidos negativos. ${ }^{20}$ MARTINS (1975) argumenta que essas fazendas não se inviabilizam do ponto de vista do cálculo capitalista porque compram o leite dos pequenos produtores familiares da montanha, que lhes vendem a qualquer preço.

SANDRONI (1980) afirma que MARTINS (1975) não verificou a contabilidade das fazendas produtoras de leite do Vale (...), ele simplesmente menciona a principal conclu- são do estudo de PAIVA (1965) (grifos do autor). A questão dos "rendimentos líquidos negativos" é de importância crucial em todo seu trabalho e para SANDRONI (1980) aí reside o principal erro do autor pois para MARTINS,

a existência de "rendimentos líquidos negativos" se deve à inserção mais profunda na economia capitalista (o que implica a necessidade de aquisição crescente de insumos produzidos na cidade) e não por uma exagerada taxa de juros calculada sobre o preço inflado da terra, cujo resultado, longe de ser um "custo" é uma expressão da mais-valia que o proprietário embolsa na forma de renda territorial. (...). Sendo assim, as conclusões de Martins, baseadas nos critérios e cálculos feitos por Paiva e Nicholls, enveredam pelo caminho de que "... as condições gerais concretas favorecem o exito do tipo contrário à produção capitalista" (...), a base desta conclusão parece-me insustentável ou pelo menos carente de qualquer possibilidade de generalização. (SANDRONI, 1980:74)

O mesmo erro é cometido por Francisco de OLIVEIRA (1972), segundo SANDRONI (1980), no trabalho em que apresenta algumas provas empíricas sobre a maior rentabilidade (ou menores custos) da pequena produção mercantil frente à grande produção capitalista. O tipo de camponês estudado por OLIVEIRA (diferente do de MARTINS), também venderia sua produção no mercado. Conforme explica SANDRONI:

(...) esse pequeno produtor teria rebaixado os preços dos produtos da sua roça (em geral produtos de subsistência) pois parte do trabalho é incorporado nas culturas ou atividades nas terras do fazendeiro. Isso permitiria o rebaixamento do custo real da alimentação e portanto, tais formas, não imediatamente capitalistas da produção agrícola, seriam funcionais e favoráveis à reprodução do capital na economia em geral e em particular nos centros urbanos (pelo lado da alimentação). (SANDRONI, 1980:84)

O trabalho do produtor direto estaria dividido então em três partes: a) uma apropriada pelo proprietário territorial; b) aquela necessária à produção de alimentos para a reprodução do próprio trabalhador; e c) nos produtos levados ao mercado para serem trocados por outros que complementam ou ampliam as necessidades do trabalhador. (idem) Esse último é de grande importância na análise, pois se existe uma redução do valor, esta se reflete justamente na quantidade de produtos levados ao mercado e nos preços obtidos nesses, e não no quantum de trabalho que é preciso para produzi-los.

Dois problemas foram apontados por SANDRONI (1980) quanto ao argumento e a correspondente base empírica utilizada por OLIVEIRA (1972). O primeiro diz respeito ao tipo de comparação feita em termos de custos entre duas formas (sítios de 1 a 4 alqueires que utilizam técnica de tração animal e pouco adubo, em relação aos que praticavam o uso de muito adubo, tração motorizada e com área de 
40 a 80 alqueires). Quanto a esse primeiro problema, SANDRONI, argumenta que por um lado, por ser a reprodução feita por PAIVA (1966) de uma pesquisa realizada por ETTORI (1966), sobre a produção de milho em São Paulo, e por outro, porque os resultados e conclusões obtidos por ETTORI (1966) são inversos aos de PAIVA (1966). OLIVEIRA (1972) utiliza os dados que PAIVA recalculou, que mostra que os rendimentos líquidos por alqueire eram maiores nos sítios de 1 a 4 alqueires do que a renda líquida das fazendas de 40 a 80 alqueires. Assim OLIVEIRA conclui que os custos da agricultura "primitiva" são inferiores aos da agricultura "moderna". (SANDRONI, 1980:91-92)

O segundo problema diz respeito à forma com que OLIVEIRA generalizou para todo o Brasil o caso especial e isolado do local analisado (Itapeva). SANDRONI, ao analisar o trabalho de PAIVA, ${ }^{21}$ verifica várias deficiências que, para ele, inutilizam o exemplo na perspectiva que é usada por Oliveira. Segundo SANDRONI, a forma de utilização dos cálculos efetivados por PAIVA - com base nos dados da pesquisa feita por ETTORI - torna-os inadequados para argumentar a tese da "funcionalidade" da pequena produção mercantil. Assim sendo, o erro de MARTINS (1975) tanto como o de OLIVEIRA (1972)

consiste portanto em haver considerado - seguramente em forma involuntária - o juro e a renda da terra como tendo a mesma natureza (em relação ao preço de custo) que o salário ou a depreciação. Isso conduz estes autores, que utilizam conceitos marxistas, a confundir no plano empírico formas aparências de mais-valia, com os elementos materiais do capital constante e variável. (SANDRONI, 1980:101)

Para SANDRONI (1980), a "inclusão" da pequena produção mercantil no capital é muito acentuada, pois todos os elementos que são incorporados ao processo produtivo dessas unidades tendem a ter seus custos transferidos para os preços. Assim, mesmo que esta produção seja realizada com base no trabalho familiar, não poderia ser atribuído a essa alguma "funcionalidade" no estilo da produção mercantil-camponesa. Segundo o autor, esta última consegue vender seus produtos por um preço inferior a seus custos de produção, pois estes são constituídos fundamentalmente de trabalho vivo e aproveitamento dos recursos naturais disponiveis (...). (ibidem, 46-47)

Um outro autor que faz alusão à tese da "funcionalidade" é Paulo Renato SOUZA (1978) que defende a idéia de que não existe uma "funcionalidade" da pequena produção mercantil para a acumulação de capital no que diz respeito à determinação dos salários e enquanto reprodutora da força de trabalho como queriam alguns autores. SOUZA (1978) refuta o argumento utilizado por alguns autores de que a pequena produção mercantil possui a função de rebaixar o custo da reprodução da força de trabalho engajada na produção capitalista, à medida que boa parte das necessidades da população assalariada de baixa renda é obtida a custos mínimos na pequena produção mercantil. Ou seja, essas formas de produção, ao cumprirem a função de produzir bens e serviços a custos menores do que se fossem produzidos por empresas capitalistas, acarretam o rebaixamento dos salários dos trabalhadores assalariados. ${ }^{22}$

Contrapondo-se a essa argumentação, SOUZA (1978) critica a validade dessa função, mostra que, em primeiro lugar, grande parte da cesta do consumo dos trabalhadores é abastecida por produtos industrializados e que, ao contrário do que se possa pensar, os preços dessas mercadorias tendem a ser mais elevados para os setores populacionais de baixa renda que se abastecem no pequeno comércio da periferia urbana. Portanto, para SOUZA (1978), os assalariados urbanos de baixa renda não estariam aproveitando do benefício de um menor custo dos produtos produzidos e/ou comercializados pelas unidades de produção mercantil simples. ${ }^{23}$ Segundo o autor, (...) a produção mercantil simples é intersticial e segue as regras ditadas pelo núcleo capitalista da economia. (...) Assim não parece em absoluto correta a idéia de que a produção mercantil simples contribua ao rebaixamento do custo de reprodução da força de trabalho. (SOUZA, 1978:101) $)^{24}$

SOUZA (1978), a partir da distinção dos conceitos de custo de reprodução da força de trabalho e salário, conclui que não é o primeiro que é baixo, e sim o segundo: (...) não é certo sequer que esse "custo" seja baixo. O que simé baixo (e muito) é o salário de base. (...) (idem). O salário seria uma forma externa de manifestação do valor da força de trabalho, podendo assumir valores acima ou abaixo deste. Para o autor, um rebaixamento do custo de reprodução da força de trabalho significa tão somente um rebaixamento do valor dos produtos que integram a cesta de consumo dos trabalhadores. Isso não implicaria qualquer variação nos salários, assim como alterações salariais não implicariam nos custos da cesta de consumo, pois segundo SOUZA (1978), a taxa de salários do sistema capitalista parece constituir-se na variável que orienta a determinação das rendas da pequena produção mercantil, e sendo assim, jamais uma economia capitalista modificaria sua taxa de salários se houvesse algum reajuste nos preços dos produtos da pequena produção mercantil.

\section{AS ANÁLISES RECENTES SOBRE A AGRICULTURA FAMILIAR: OS ANOS 90}

Até o momento podemos dizer que as críticas ao dualismo não conseguiram dar conta inteiramente do que se passava na agricultura. Ao enfatizar a "funcionalidade" da pequena produção familiar, verificamos que não se deu atenção suficiente ao novo padrão de desenvolvimento pelo qual passa o campo, assim como nas críticas à tese da "funcionalidade" da pequena produção, que não tiveram qualquer dificuldade em mostrar que esses estabelecimentos menores (tanto em área como em valor da produção) tinham importância econômica irrisória. Nota-se que no meio acadêmico o tamanho dos estabelecimentos era considerado a principal diferença entre as formas de produção. Ao ser examinada 
com cuidado a questão do tamanho das unidades de produção na agricultura, percebe-se que este não é o aspecto mais relevante, a importância econômica das unidades produtivas está ligada muito mais à possibilidade de adoção de inovações tecnológicas (que eleva a dimensão dos meios de produção), à localização e à qualidade do solo, do que ao tamanho inicial do estabelecimento.

A partir de meados da década de 80 as preocupações com a produção familiar passam pela forma contraditória do novo processo de desenvolvimento, uma nova linha de análise sobre a produção familiar buscando compreender o sentido econômico e social da presença dessa unidade de produção diante das novas condições técnicas e de produtividade do trabalho na agricultura brasileira, enfim, do processo de modernização. A partir do final dos anos 80 , o debate se volta para o papel e os espaços que esse tipo de produção passaria a exercer e ocupar no sistema capitalista, surgindo também alguns esforços para avaliar a importância social e econômica da agricultura familiar no Brasil (caracterizando seus principais segmentos).

Podemos verificar que o processo de modernização agrícola das últimas décadas criou uma série de problemas sociais perversos dentre eles os conflitos pela posse da terra e os antagonismos entre diferentes tipos de capital — essa é a parte mais visível desse processo contraditório, ao mesmo tempo a inserção da unidade de produção familiar no processo de desenvolvimento agrícola brasileiro tem-se intensificado diante das novas mudanças. Verifica-se com o desenvolvimento desse processo um aprofundamento das relações de produção capitalista no interior do setor rural, pode-se dizer que esse processo contribui para a expansão e o aprofundamento de diferentes processos que conduzem à proletarização da força de trabalho rural, todavia essa direção - rumo à proletarização — não é exclusiva, isso implica na afirmação de que a presença do capital no processo de modernização e industrialização da agricultura não é sinônimo de expropriação do conjunto de produtores presentes no campo. Isso se explica pelo fato do desenvolvimento capitalista da agricultura apresentar um caráter particular, fruto entre outras coisas - das limitações impostas pela natureza.

Partindo desse ponto de vista, podemos admitir que a consolidação do desenvolvimento capitalista na agricultura não eliminou a unidade de produção familiar, ao contrário, propiciou a intensificação do seu processo de diferenciação. Um exemplo é o surgimento de um segmento da produção familiar que - devido à modernização agrícola - se constitui ou se transforma em uma "empresa capitalista" embora continue organizando sua produção em torno do trabalho familiar, essa passa a participar do processo de reprodução do capital.

Diante desse contexto, a pesquisa de KAGEYAMA e BERGAMASCO (1989) mostra que esse processo de modernização e industrialização da agricultura brasileira provocou transformações profundas na estrutura social da produção no campo. Neste trabalho, as autoras ao classificarem as unidades produtivas através de uma variável base - composição da força de trabalho utilizada nos estabelecimentos, diferenciando entre trabalho familiar e trabalho contratado - e dois outros critérios (área total e utilização de tratores), fizeram uma estruturação das unidades produtivas em quatro categorias básicas que resultaram depois em oito categorias finais, mostrando a heterogeneidade desses grupos. Dessa forma, foi feita uma caracterização dessas unidades produtivas e uma avaliação da importância dessas categorias na produção agrícola nacional.

Através dos dados censitários as autoras identificaram que dos 5,2 milhões de estabelecimentos agropecuários recenseados, 3,7 milhões ocupavam mão-de-obra familiar. Esses estabelecimentos familiares ocupavam mais de $150 \mathrm{mi}-$ lhões de hectares, ou seja, 42,3\% da área total e neles estavam $74 \%$ das pessoas ocupadas na agricultura brasileira. (KAGEYAMA e BERGAMASCO, 1989:62) Com base nesses dados pode-se dizer que a agricultura familiar era responsável por mais de $70 \%$ dos estabelecimentos agrícolas no Brasil, isso demonstra que esse grupo de agricultores que possuía um espaço "restrito", ${ }^{25}$ passou a desenvolver estratégias familiares para sua manutenção, diante da necessidade de adaptar-se a um novo contexto socioeconômico, ao mesmo tempo que passaram por significativas transformações em relação a sua forma de produzir e em sua vida social.

Segundo KAGEYAMA e BERGAMASCO (1989), não se deve considerar a produção familiar como um segmento autônomo, com uma racionalidade econômica própria diferente daquela que está presente na economia capitalista. A particularidade dessas unidades produtivas em relação ao restante da agricultura capitalista, está na sua dependência - em maior ou menor grau — do trabalho direto dos membros da família proprietária dos meios de produção. Sua racionalidade econômica é, assim como na "empresa capitalista", a busca de um excedente da produção, o que não impede que esses produtores se insiram no sistema produtivo e nos mercados capitalistas. (p.62)

\subsection{O papel e os espaços da agricultura familiar}

Diante da importância que a agricultura familiar vem adquirindo no agro brasileiro, vários autores passaram a priorizar esta enquanto objeto central de suas análises, sendo que o papel e os espaços que estas unidades de produção têm assumido vêm sendo destacados. Um conjunto de preocupações surge no que diz respeito ao papel e aos espaços da agricultura familiar hoje e no futuro, ou seja, a importância que a agricultura familiar adquiriu na sociedade tem levado os próprios agricultores a desenvolverem estratégias e se prepararem para ocupar um espaço importante na construção de um novo modelo de agricultura para o País, uma agricultura não latifundiária, não predatória e não excludente.

Neste contexto a procura por uma nova agricultura levou vários autores a analisarem o lugar da agricultura familiar no processo de modernização, colocando no bojo das discussões duas questões: em que grau e de que maneira a agricultura familiar foi atingida por esse processo; e qual o espaço atual deste setor.

Quanto à primeira questão que se coloca - forma com que a agricultura familiar foi afetada pelo processo de 
modernização — é preciso enfatizar alguns aspectos. O primeiro diz respeito ao perfil tecnológico desse processo, que foi amplamente discutido por vários autores, entre eles GRAZIANO DA SILVA et. all. (1983). Segundo este, o padrão tecnológico adotado e difundido não foi adequado às necessidades da agricultura familiar, porque as próprias características estruturais da agricultura familiar não se adequam ao padrão tecnológico disponível. Isso porque o acesso à moderna tecnologia é limitado pela disponibilidade de terras, pelas próprias condições dessas, pelo fato desses terem que desenvolver várias culturas, pela insuficiência de recursos para investimento e por necessitar de mão-de-obra em maior número.

Dentre essas, algumas razões econômicas como o fato de não terem sido criadas tecnologias que pudessem adaptar-se à pequenas escalas de produção, e também razões políticas como a inexistência de mecanismos que viabilizassem o amplo acesso à modernização e aos seus benefícios por parte dos agricultores familiares. Além disso, o crédito, a pesquisa e a extensão rural também foram direcionados para os grandes produtores. Entretanto não se pode ignorar aqueles produtores familiares que por vários motivos integração com agroindústrias, concorrência, e mecanismos de financiamentos - conseguiram participar desse processo de modernização.

Na pesquisa coordenada por LAMARCHE (1993), a comparação feita na parte brasileira mostra que os produtores de Ijuí (RS) que passaram por um processo de modernização da produção mais intenso, não é o que apresenta os melhores resultados econômicos e sociais, sendo superado pelos produtores de Leme (SP) onde a modernização tecnológica não foi tão forte.

A capacidade de competição da agricultura familiar no mercado capitalista é um outro aspecto que deve ser considerado. MOREIRA (1995) refere-se à agricultura familiar enquanto uma "forma social já constituída, e portanto já integrada e sujeita à lógica competitiva desta integração". Neste trabalho o autor enfoca a sociabilidade mercantil das formas sociais da agricultura familiar na competição intercapitalista. Dado o caráter concentrado da propriedade de terras e dos mercados no Brasil, a agricultura familiar - tradicionalmente subordinada - encontra-se num contexto de modernização que implica na monetarização crescente das relações, ao mesmo tempo em que é exposta a uma rede cada vez maior de interrelações, o que faz com que sua capacidade de resistir à exploração diminua.

Outro aspecto a ser ressaltado em relação à capacidade de reprodução da agricultura familiar diz respeito ao processo de valorização da terra que acompanha a modernização. A terra transformada em ativo financeiro passa a ser objeto de especulação, aumentando as dificuldades dos agricultores familiares para adquiri-las. Esse fato contribuiu para a expulsão de moradores, parceiros e meeiros para áreas de fronteiras e também contribuiu para que alguns membros da família desses produtores fossem à procura de trabalho temporário para que pudessem complementar sua renda, dada a impossibilidade de ampliar suas áreas para produzir.

Nesse contexto a luta pela terra passa a ser uma estratégia desses agricultores para assegurar sua reprodução. Os produtores familiares brasileiros concentram seus esforços em torno do acesso à terra, sendo a compra de terras o principal objetivo. De um lado, as unidades de produção que são vistas enquanto capitalizadas entram na luta pela terra por ser o tamanho da propriedade um dos fatores que influenciam na aquisição do crédito rural financiado pelo governo federal, e com isso garantir seu espaço no mercado. De outro, estão os pequenos produtores que lutam pela terra para garantir a reprodução da sua unidade de produção, ou seja, tenta adquirir novas terras para garantir o futuro da família. Na maior parte dos casos, esse desejo esbarra em alguns obstáculos, primeiro a terra é muito cara e segundo esses agricultores não possuem recursos suficientes para comprá-las.

O processo de valorização de terras não se dá somente com terras produtivas, mas também, a valorização das terras improdutivas, que acabam funcionando como reserva de valor, e abrindo a possibilidade de uso bastante flexível para os que mantêm um estoque privado de terras. ${ }^{26}$ Segundo MOREIRA (1995), essa flexibilidade envolve não só a possibilidade de se produzir diversas mercadorias, mas principalmente, "uma flexibilidade de utilização não propriamente agrícola, tais como: usos urbanos, mineração, energia elétrica, lazer, turismo e, futuramente, recursos da biodiversidade". (p.11)

Diante desses aspectos que demonstram de que forma a agricultura familiar foi afetada pelo processo de modernização, podemos verificar que este setor sofreu, um profundo processo de diferenciação social. De um lado uma parte desses produtores por serem expropriados, acabaram fazendo parte da massa de assalariados permanentes ou temporários rurais e urbanos. De outro, os que mantiveram seus meios de produção desenvolveram-se basicamente em três direções: alguns acabaram integrando-se às agroindústrias e cooperativas; outros recorreram a pluriatividade, ou seja, à combinação do trabalho familiar na agricultura com outras atividades; e ainda, outros conseguiram tecnificar-se e especializar-se, passando a competir no mercado e também a sujeitar-se diretamente aos mercados monopolizados.

Grande parte dos autores consideram que em todos os casos a subordinação está presente, levando a uma dificuldade de reprodução desses agricultores familiares. Devido a esses fatores, esses agricultores passam a desenvolver e diversificar suas estratégias de sobrevivência, criando em conseqüência uma diversidade dentro do meio rural. Partindo desse ponto de vista, alguns autores argumentam que o espaço da agricultura familiar dificilmente deixará de ser o espaço da subordinação. Segundo MOREIRA (1995), no caso da agricultura familiar já existente, "o espaço que se abre é o de uma diferenciação social interna: que ao mesmo tempo que integra alguns, exclui outros". (p.15)

Paralelamente a essas preocupações sobre o papel e o lugar da agricultura familiar, duas outras abordagens teórico-metodológicas fornecem referência ao estudo da agricultura familiar, uma primeira onde os textos tentam conhecer os processos sociais de desenvolvimento de outras sociedades enfatizando o papel da agricultura familiar no desenvolvimento capitalista dos países desenvolvidos, e uma segunda onde são feitas abordagens comparativas, seja entre categorias de produtores e situações locais ou regionais dentro do nosso país, sejam comparações internacionais. 
No que diz respeito à primeira abordagem teóricometodológica, enfatizaremos os trabalhos de VEIGA (1991) e ABRAMOVAY (1992), que enfatizam o papel da agricultura familiar no desenvolvimento capitalista dos países desenvolvidos, rejeitando, portanto, a hipótese da sua tendência ao desaparecimento.

VEIGA (1991) faz uma análise histórica da agricultura nos países desenvolvidos e conclui que durante o período de grande impulso do desenvolvimento capitalista meados de 30 e início de 70 - foi a agricultura familiar que acabou se afirmando nos países desenvolvidos. Para explicar a permanência dessa unidade de produção, VEIGA buscou argumentação no trabalho de Cochrane, que tem seu esquema explicativo popularizado através da imagem do "treadmill". ${ }^{27}$ A implementação das inovações tecnológicas desses países é vista num quadro em que o governo introduz uma política de sustentação de preços para garantir alimentos e matérias primas a baixos custos - com relação às formas empresariais - à sociedade abrangente. Assim, VEIGA conclui que um maior número de produtores consegue garantir a obtenção de lucro aumentando a concorrência pela aquisição de ativos fundiários daqueles que não introduziram a inovação em tempo hábil. Isso leva a um aumento do preço da terra, que sobrecarrega os custos da produção, fazendo com que a taxa de lucro do setor agrícola seja menor do que a dos outros setores. Nesse caso o produtor familiar aceita esta situação trocando renda corrente por maior renda futura. Portanto para VEIGA, a agricultura familiar adiaria a rentabilidade corrente - lucro corrente — por uma rentabilidade futura, que seria obtida no momento da venda das terras. $^{28}$

Segundo VEIGA, essa política "pode estabelecer tratamento diferenciado aos vários ramos do setor, engendrando diversos ritmos de sustentação de preços". No caso dos países desenvolvidos essa política vem acompanhada de outras políticas viabilizadoras da produção familiar, que vão da pesquisa à organização dos mercados, passando pelas mais diversas formas de assistência técnica, financeira, educacional, habitacional, previdenciária, etc. Num trabalho mais recente, VEIGA (1995) afirma que em todos os países desenvolvidos a modernização da agricultura seguiu uma "via democrática", onde o sistema agrário historicamente constituído se conformou em base de pequenas propriedades apostando nas virtudes da agricultura familiar. E mais, afirma que não há exemplos em que a dita "via prussiana" — com elevado grau de concentração de terras e onde a propriedade da terra é um elemento na disputa intercapitalista - tenha "permitido o pleno desenvolvimento de uma nação" (VEIGA,1995:129).Nesse último caso, as elites agrárias tornam-se importantes elementos constitutivos da ordem e do poder político, como é o caso do Brasil.

Outro trabalho que procura ressaltar a adaptabilidade da agricultura familiar às exigências do desenvolvimento capitalista é o de ABRAMOVAY (1992). O autor enfatiza, no estudo da estrutura social do desenvolvimento capitalista das nações centrais, que a modernização da agricultura que promoveu altas produtividades e uma importante tecnificação, teve, historicamente, como base a agricultura familiar e não o uso intensivo de trabalho assalariado. Assim o autor refutou a idéia de que a agricultura familiar desapareceria porque não estaria apta a incorporar o progresso técnico.

Quanto à segunda contribuição teórica, a pesquisa coordenada por LAMARCHE (1993) onde foram realizadas comparações internacionais em cinco países - Brasil, Polônia, Tunísia, Canadá e França - é de grande importância para os estudiosos desse tema e que se interessam em discutir o futuro da agricultura no Brasil, pois um dos objetivos desta concentrou-se em precisar o universo da agricultura familiar no que diz respeito aos seus aspectos de diversidade e modos de funcionamento frente à diferentes realidades. Dois volumes foram publicados, ${ }^{29}$ no primeiro já traduzido em português, os autores enfocam a problemática da agricultura familiar do ponto de vista teórico, explicam a metodologia adotada na pesquisa e apresentam um esboço da situação e do funcionamento da agricultura familiar nos países pesquisados. ${ }^{30}$

O ponto básico da pesquisa é a constatação pelos autores de que a exploração familiar - definida como aquela em que há uma interdependência entre propriedade, trabalho e família - assegura em maior ou menor grau, independente do sistema sócio-político e das evoluções históricas, a produção agrícola dos países. Ou seja, quando essa representa a possibilidade de uma maior inserção numa economia de mercado, ou por permanecerem "arcaicas" e baseadas ainda numa economia de subsistência, ou então por serem a única forma capaz de satisfazer as necessidades essenciais do conjunto da sociedade como um todo, e finalmente mesmo quando excluída de todo desenvolvimento, ou mesmo tolerada quando não eliminada totalmente. (LAMARCHE, 1993:13). Essa variedade de situações particulares demonstram a capacidade de adaptação da exploração familiar e a heterogeneidade desta, segundo os autores, a exploração familiar "contem nela mesma toda a diversidade".

Toda reflexão feita pelos autores possui um eixo definido pelo grau de integração da exploração familiar na economia de mercado. Considerando que um determinado grau de integração com o mercado corresponde com uma determinada relação com a sociedade, um determinado modo de vida e de representação. Assim foi traçado um eixo segundo o grau de integração com o mercado, onde os pesquisadores buscaram o entendimento do modo de funcionamento das explorações familiares estudadas a partir de um "modelo original" 31 e de um "modelo ideal". ${ }^{32}$

Não entraremos aqui na comparação feita entre os países pesquisados, nos interessa o trabalho realizado no Bra$\mathrm{sil}^{33} \mathrm{e}$ as análises e conclusões deste. Segundo WANDERLEY (1995), algumas conclusões podem ser retiradas dessa pesquisa. Notou-se que há no Brasil fortes restrições ao funcionamento da agricultura familiar, o acesso à terra - enquanto condição necessária para essa atividade - mostrase o mais grave delas, juntamente com o modelo de modernização assumido na agricultura brasileira, onde por um lado, o produtor que não atinge um determinado patamar tecnológico está sujeito a desqualificação, e por outro esse modelo, por possuir um caráter parcial e incompleto, acaba por levar os produtores a recorrer ao trabalho assalariado de terceiros para a manutenção de algumas atividades manuais do processo produtivo. No caso desse estudo, as 
estratégias dos produtores e de suas famílias estão norteadas por essas restrições.

Nos trabalhos mais recentes, algumas perspectivas estão sendo apontadas para a agricultura familiar principalmente no sentido de criar espaços para esse setor na sociedade brasileira. E mais, criar espaços para que a agricultura familiar desenvolva suas potencialidades e - quem sabe transformar-se em agente do progresso. ${ }^{34}$

\section{CONSIDERAÇÕES FINAIS}

O objetivo do trabalho, como definido na introdução, foi de apresentar uma breve revisão teórica sobre a agricultura familiar no Brasil, mostrando os rumos dos debates desde a década de 60 até os dias atuais. Os debates, além de serem muito polêmicos, são bastante complexos e multifacetados, por isso não coube à nós abrangê-los em toda sua plenitude, mas apenas contextualizar as discussões e apresentar as diversas posições.

Através dessa revisão podemos verificar que a agricultura familiar tornou-se um tema importante na agenda de várias instituições de pesquisa e universidades. Muitos trabalhos tem sido realizados na tentativa de quantificar a agricultura familiar, a exemplo dos trabalhos já citados nessa revisão ${ }^{35}$ e de trabalhos regionalizados que vem sendo realizados à partir da década de $90 .^{36}$

Podemos dizer que a agricultura familiar tem recebido uma atenção maior entre os estudos do meio rural, primeiro porque existe um grande contingente de pessoas que ainda vivem no campo e a grande maioria - como já enfatizamos durante o trabalho - estabelecidas em unidades de produção familiar. Segundo, alguns estudos tem demonstrado as vantagens desse tipo de produção em algumas atividades, culturas e regiões, assim como o potencial de crescimento econômico desses agricultores.

Tanto os métodos, os pressupostos teóricos, as hipóteses e os resultados quantitativos desses trabalhos não são idênticos, isso demonstra um sinal de vitalidade, que esse terreno é tão fértil ao ponto de se constituir um objeto de estudo a ser muito pesquisado daqui para frente.

Diferente do que aconteceu com a "pequena produção", que desde a década de 1970 ao final de 1980 , onde verifica-se uma unanimidade entre os pesquisadores de que não parecia mais haver dúvidas que esta categoria estava em fase acelerada de extinção social. A agricultura familiar ao contrário, tem-se mostrado mais dinâmica no que diz respeito ao seu papel social significativo e ao seu potencial econômi$\mathrm{co}$, tanto que suas limitações como também suas possibilidades de crescimento tem sido ressaltadas, assim como sua viabilidade técnica e política (para médio e longo prazos).

Dentro desse quadro de preocupações pelo qual a agricultura familiar está passando e tendo em vista as perspectivas teóricas aos quais abordamos neste trabalho, podemos nos perguntar então: o que aconteceu de novo com esta questão? Houve mudança? Como se explica essa mudança?

Ao que podemos perceber é que não se trata de retomar um velho tema, pois as pesquisas sobre a agricultura familiar estão nos dando produtos e resultados novos. Isso porque houve não só mudança nas técnicas e nos métodos de pesquisa, mas principalmente porque houve mudanças importantes nas bases teóricas desses novos trabalhos.

No que diz respeito às mudanças de técnicas e métodos de pesquisa sobre a agricultura familiar, verificamos que os novos trabalhos ${ }^{37}$ não delimita mais a agricultura familiar com relação à superfície dos estabelecimentos agrícolas. As pesquisas baseadas nestes métodos tendiam a confirmar a idéia de que relevantes do ponto de vista social, a "pequena produção" possuía um peso econômico cada vez menor. Daí concluía-se que estas unidades de produção estariam fatalmente condenadas ao desaparecimento.

Então o que mudou do início da década de 1990 até agora no que diz respeito ao ambiente intelectual onde parecia que já havia sido dito tudo sobre a agricultura familiar?

A mudança que podemos verificar é com relação a assimilação conceitual entre agricultura familiar e "pequena produção" (condenada à extinção), esta deixou de ser aceita como uma evidência adquirida a partir de dois tipos de pesquisa que citamos neste trabalho.

Primeiro pelos trabalhos da década de 80 que demonstraram que existia, no Brasil, agricultores familiares diferentes do que era conhecido por "pequenos produtores". ${ }^{38}$

Segundo, os estudos sobre a estrutura social do desenvolvimento capitalista da agricultura em países capitalistas avançados, ${ }^{39}$ que mostram que a agricultura familiar foi a base do desenvolvimento agrícola desses países.

Através dessas pesquisas pode-se perceber que a base social do desenvolvimento agrícola foi a unidade de produção familiar nas nações de capitalismo central — Estados Unidos, Canadá, Europa Ocidental, Japão e recentemente Tigres Asiáticos.

Nesta comparação nos interessa mostrar que nos países e regiões que tiveram essa modalidade de crescimento agrícola, o desenvolvimento se deu de forma menos excludente e mais articulado do que naquelas onde o acesso à terra eram um obstáculo ao desenvolvimento.

Essa característica da agricultura nesses países capitalistas desenvolvidos também contribui para mostrar que o desenvolvimento do capitalismo no campo não significa que as unidades de produção familiar estejam condenadas ao desaparecimento, e que essas só existiram onde o capitalismo ainda não estivesse se desenvolvido.

Assim, é importante verificar que longe de ser uma forma social condenada pela história, a agricultura familiar pode ser - tanto que é em circunstâncias históricas variadas a exemplo do Canadá e da Europa - a base do desenvolvimento agrícola. Portanto, esses exemplos se apresentam como uma nova base teórica para uma perspectiva de transformação que pode interferir nos programas de pesquisa brasileiro. 
NOTAS

Vale ressaltar aqui que nem sempre o conceito agricultura familiar foi empregado nos estudos. Os conceitos de campesinato e de pequena produção também foram utilizados, variando conforme a época, realidade específica a que se aplica ou abordagem teórica adotada.

2 Segundo PALMEIRA (1984), as relações de produção eram vistas como "herança do passado" ("colonial", "feudal", "escravista", "capitalista", ou outro qualquer). Havia uma concepção de que as respostas para as questões do presente estavam no passado, assim para entender as relações de produção e as relações sociais no seu conjunto era preciso ir ao passado. Recuava-se até os primórdios da colonização e às vezes achavam esse insuficiente e recuavam até Portugal.

${ }^{3}$ Os autores ao buscarem as respostas sobre as relações de produção atuais, além de trazerem uma "linha genealógica que une o latifúndio contemporâneo à forma de produção de sua escolha no passado", trazem também "um conceito previamente construído de latifúndio". Existe um cuidado por parte dos autores de "não pensarem o latifúndio apenas nos termos de grande extensão de terras", mas um latifúndio caracterizado pelo monopólio da terra, tecnologia atrasada, relações de produção e trabalho com dependência pessoal, ligação com o exterior, particularidades geográficas e particularidades históricas. (PALMEIRA, 1984:22)

${ }^{4}$ Nesse caso específico da parceria, os autores defensores das duas teses referiram-se ao mesmo texto de MARX (do livro III de "O Capital", onde $\mathrm{O}$ autor aborda a renda fundiária) no qual a parceria é vista como uma forma de transição. VINHAS (1972) argumenta que a retribuição do trabalho in natura, isto é, em espécie, é uma das características típicas de "restos feudais" e que, assim como Marx, a renda absoluta da terra, a exploração do trabalho rural e outras formas "atrasadas" que estão presentes no meio rural expressam relações "pré-capitalistas". O argumento de PRADO JR (1966) é de que a parceria brasileira em nada parece com a da Europa e representa uma forma de remuneração do trabalho, para os defensores da tese capitalista, o parceiro brasileiro é apenas um assalariado disfarçado. Vale lembrar que os defensores das duas teses estão de acordo quanto à distancia existente entre a parceria brasileira e a parceria "clássica".

5 Estes estudos demonstravam uma concepção evolucionista do processo histórico, ao visualizar no Brasil a sucessão das etapas feudalismo e capitalismo tal qual como nos países europeus.

${ }^{6}$ No contexto da evolução dos processos de industrialização e modernização, a obra coordenada por GRAZIANO DA SILVA (1980a), "Estrutura Agrária e Produção de Subsistência na Agricultura Brasileira", emerge da polêmica sobre a vitalidade da pequena produção e da proletarização do trabalhador rural. Neste trabalho a importância da pequena produção familiar no contexto da agricultura brasileira é ressalta$\mathrm{da}$, juntamente com a situação de extrema pauperização em que vivem os pequenos produtores, que revelam através do seu padrão de vida a violenta exploração a que estão submetidos. Esse estudo dá uma visão ampla da agricultura brasileira na medida em que tem em vista as grandes regiões e os principais produtos cultivados.

Para o autor não capitalistas constituem formas de relaçōes sociais que não têm a temporalidade das relações pré-capitalistas e que são contemporâneas das relações capitalistas de produção. As relações nãocapitalistas de produção, determinadas pelo processo de reprodução ampliada do capital, são uma outra forma desse processo, mediação diversa da mediação do trabalho assalariado na acumulação de capital. Assim para MARTINS, a concepção de não-capitalista preconiza a produção de algo novo não-capitalista, mas sob a égide do capital, de forma desigual e sob condições específicas e contraditórias da relação capitalista. Dessa forma o capital tem o poder de produzir relações sociais não-capitalistas. (MARTINS,1986:149)

${ }^{8}$ O principal efeito social do novo padrão tecnológico seguido pela agricultura brasileira foi a subordinação cada vez mais efetiva da força de trabalho ao capital, através do seu controle sobre a intensidade e o ritmo de trabalho, causando consequentemente algumas alterações nas próprias relações de emprego. KAGEYAMA, A., et all. (1983), p.41.

- Segundo ABRAMOVAY (1992), o agricultor moderno familiar é um exemplo desse trabalhador para o capital, pois embora esse não seja um proletário, o agricultor familiar cumpre socialmente a mesma função que o assalariado (...). (p.326)

${ }^{10}$ Cadernos do CEAS, $n^{\circ}$ 9, 1980.

${ }^{11}$ SANTOS, foi um dos primeiros autores no Brasil a estudar a produção familiar integrada às agroindústrias processadoras, utilizando o conceito marxista de subordinação formal.

${ }^{12} \mathrm{O}$ conceito de subordinação formal e real foram utilizados com o mesmo sentido que os conceitos marxistas de subsunção formal e real constantes no capítulo inédito do livro "O Capital" (MARX, 1978) que serviram de base para novas análises sobre a articulação entre o capital e a pequena produção. A subsunção formal corresponde à subordinação, pelo capital, de um processo de trabalho pré-existente ao processo capitalista, através do prolongamento do tempo de trabalho, isto é, sob a forma de extração de mais-valia absoluta. (MARX, 1978:5165). Nesse estágio da produção capitalista ainda não se verifica uma transformação plena do processo de produção. Por sua vez a forma de subsunção real encerra uma plena transformação do processo de trabalho e suas condições reais, esta se dá quando há extração de mais-valia relativa, isto é, o modo de produção capitalista transforma o próprio processo de trabalho. (MARX, 1978:55-56 e 66-70). Segundo Marx, "com a subsunção real do trabalho no capital efetua-se uma revolução total (que prossegue e se repete continuamente) no próprio modo de produção, na produtividade do trabalho e na relação entre capitalista e operário." (MARX, 1978:89)

O conceito de subordinação formal do trabalho ao capital também estão presentes nos trabalhos de LIEDKE, (1977), CRAVO, (1982) e RIZZI, (1984). Esses estudos de caso elucidam diversas características do trabalho do produtor integrado que aparentemente sustentam a propriedade do conceito marxista utilizado.

${ }^{13}$ Com relação à subordinação às agroindústrias, o trabalho de SORJ (1982) sobre a produção avícola integrada de Santa Catarina, mostra que os pequenos proprietários organizados em base no trabalho familiar possuem um "contrato de integração" com as agroindústrias que não impõe apenas o preço e as condições de pagamento, mas estabelece clausulas determinando a própria "maneira de produzir" dessas unidades de produção familiar. *****

${ }^{14}$ Grifo nosso.

${ }^{15}$ Para ABRAMOVAY (1992) a idéia de "maturidade" deve ser questionada, pois além da agricultura brasileira possuir excesso de trabalho pouco produtivo, terras subutilizadas, enfim um caráter desigual de desenvolvimento, essa deve ser colocada em questão pela natureza do seu setor mais moderno que mesmo integrado à agroindústria e utilizando produtos industriais na produção, apoia-se no trabalho assalariado em larga escala e não tem-se mostrado capaz de desempenhar a função crucial de rebaixamento durável dos preços alimentares que nos países avançados a agricultura cumpriu. (p.328-329)

${ }^{16}$ Como queriam alguns estudos realizados na década de $60-$ como o de PALMEIRA (1971), que atribuíam um caráter transitório a essas relações, no sentido de que estas seriam no decorrer da história, superadas com a dominação definitiva do capital.

${ }^{17} \mathrm{Na}$ década de 50 , quando o processo de industrialização venceu sua primeira etapa, ficou evidente um contraste entre o setor urbano em rápida expansão e modemização e a permanência de um "atraso no campo". Esse fato deu lugar a interpretações dualistas, que se baseavam no pressuposto de que no Brasil haviam duas estruturas: uma atrasada e outra adiantada, ou seja, havia um setor industrial dinâmico e uma agricultura de subsistência que precisava ser desenvolvida., Essa oposição entre um setor atrasado e um moderno caracterizava a singularidade da formação histórico-econômica do país. Esta idéia de dupla estrutura serviu como justificativa para as políticas de modernização do campo brasileiro que justificavam que se desenvolvesse o setor "atrasado", o país deixaria de ser subdesenvolvido. Em seu trabalho OLIVEIRA pretende demonstrar que tal dualidade além de não se sustentar como singularidade, à medida em que se encontra em quase todos os sistemas e em quase todos os períodos, constitui-se na maioria dos casos, em um aspecto formal, pois "(...) de fato, o processo real mostra uma simbiose e uma organicidade, uma unidade de contrários, em que o chamado 'moderno' cresce e se alimenta da existência do 'atraso' (...)". (OLIVEIRA, 1972:27)

${ }^{18}$ Para SILVA, a subordinação das relações pré-capitalistas ao capital não pode ser compreendida como uma funcionalização dessas relações.

19 As críticas desse autor foram sobre a relação entre o preço dos produtos agrícolas e os salários urbanos.

${ }^{20}$ Confirmando os dados de PAIVA e NICHOLLS (1965).

${ }^{21}$ PAIVA toma emprestados os dados de ETTORI para efetuar seus próprios cálculos. Seus resultados são inversos aos de ETTORI no que diz respeito à rentabilidade das menores e das maiores unidades. Ver SANDRONI,1980: 93-100. 
${ }^{22}$ Dentre os autores que defendem essa tese ver OLIVEIRA (1972).

${ }^{23} \mathrm{O}$ trabalho de SOUZA (1978), buscando compreender o funcionamento do mercado de trabalho em economias cujo desenvolvimento capitalista industrial é recente. Mesmo assim, é possível aplicar a análise do autor aos produtos agrícolas in natura, na medida que o próprio faz uma breve referencia às vinculações entre as formas de organizações rurais com o tema geral tratado.

${ }^{24}$ Quando SOUZA (1978) manifesta a idéia de a produção mercantil simples ser "intersticial" e seguir regras do sistema capitalista, está pressupondo o fato de que a economia não é dual, ou seja, que cada uma de suas "partes" está articulada e servindo de alguma forma à expansão do capital, estando a ele, portanto, subordinada. Segundo SOUZA essa subordinação pode dar-se de duas formas: a) no que diz respeito ao espaço econômico a ser ocupado no mercado (que é determinado pelo capital) e, b) pela extração de excedente.

${ }^{25}$ Segundo Wanderley (1995), a grande propriedade sempre foi o modelo socialmente reconhecido, foi quem recebeu estímulo social expresso na política agrícola, onde se tentou assegurar sua modernização e reprodução. Ao contrário, a agricultura familiar ocupou um lugar secundário na sociedade brasileira, impossibilitando de desenvolver suas potencialidades enquanto forma social específica de produção. (p.38)

26 Ver MOREIRA (1981).

${ }^{27}$ Segundo VEIGA, esse é um sistema desenvolvido para puxar água do poço que utilizava força do andar humano, sem sair do lugar.

${ }^{28}$ Para MOREIRA (1995), Veiga faz uma confusão entre lucro e realização da renda da terra e é por detrás disso que entende a venda da terra como uma "realização adiada desse lucro". Para MOREIRA, a valorização das terras e a sua realização na venda beneficia os pequenos e também os grandes proprietários e por isso " não são elementos que podem caracterizar uma especificidade da agricultura familiar frente à agricultura empresarial". (p.12)

${ }^{29}$ LAMARCHE, (1993).

${ }^{30}$ Foi feito uma classificação para definir as sociedades estudadas no nível global, quatro tipos foram elencados: as sociedades no sistema capitalista avançado (Canadá e França); as sociedades do sistema capitalista dependente (Brasil); as sociedades em via de desenvolvimento (Tunísia); e, finalmente, as sociedades no sistema coletivista (Polônia).

${ }^{31}$ Esse modelo original diz respeito ao sistema de valores e ambições para o futuro, sendo que se apresenta muitas vezes distinto nas diferentes sociedades pesquisadas e mesmo quando ocorrem modelos originais idênticos, os produtores possuem valores e ambições diferentes, mostrando assim uma capacidade de adaptação a novas situações. (LAMARCHE, 1993:19)

${ }^{32} \mathrm{O}$ modelo ideal refere-se ao futuro, ou seja, a partir da projeção que o produtor faz de sua exploração para o futuro, esse passa a organizar estratégias e a tomar decisões orientados e em direção à situação esperada. (LAMARCHE, 1993:19)

${ }^{33}$ No Brasil foram estudadas três áreas profundamente diferentes - Cariri da Paraíba (Nordeste), Leme (São Paulo) e Ijuí (Rio Grande do Sul) cada um desses modelos possuem características próprias e funcionam diferentemente de acordo com as particularidades do processo de desenvolvimento da agricultura regional, a primeira centrada no controle latifundiário, a segunda na grande propriedade patronal e a última na tradição camponesa. (WANDERLEY, 1995:57)

${ }^{34}$ Não nos cabe aqui fazer uma discussão em torno dessas perspectivas pois nosso trabalho consiste numa revisão teórica, e essas perspectivas dizem respeito a questões conjunturais não sendo o momento oportuno para tais discussões. Dentre as perspectivas apontadas para a agricultura familiar estão: a política agrícola; a questão da sustentabilidade ambiental; o impacto de novas tecnologias; o desdobramento da discussão em torno da reforma agrária e a evolução da inserção internacional do país, entre outras questões.

${ }^{35}$ KAGEYAMA e BERGAMASCO, 1989.

${ }^{36}$ No estado de São Paulo com ABRAMOVAY et al., 1995; em Santa Catarina, CEPA/SC, 1994; e no estado do Paraná, ASSESOAR, 1994. O primeiro trabalho mostra que a agricultura familiar no estado de São Paulo corresponde à um terço do valor da produção. Em Santa Catarina e no Paraná a preocupação era de tipificar as diferentes modalidades de existência de agricultura familiar nos respectivos estados.

${ }^{37}$ KAGEYAMA e BERGAMASCO (1989), ABRAMOVAY et al (1995), CEPA/SC (1994) e ASSESOAR (1994).

${ }^{38}$ Mesmo estando subordinados ao capital, haviam produtores que utilizavam o crédito bancário, arriscavam-se no mercado, integravam-se às agroindústrias, tecnificavam-se e modernizavam-se, produziam para mer- cado interno e externo, enfim, não eram produtores de subsistência.

39 Assim como os trabalhos de ABRAMOVAY (1992), VEIGA (1995), LAMARCHE (1993)

\section{REFERÊNCIAS BIBLIOGRÁFICAS}

ABRAMOVAY, R. De camponeses a agricultores: paradigmas do capitalismo agrário em questão. Campinas, 1990, (tese de doutorado/ UNICAMP).

CRAVO, V. Z. Lavoura de fumo em Irati: a produção familiar e capitalismo. Curitiba, Estante PARANISTA 17, 1982

CORBUCCI, R. C. Algumas reflexões sobre o Programa Nacional de Agricultura Familiar. Reforma Agrária. Revista da ABRA, 2-3 (25), maidez/ 1995. pp. 178-184.

DAL-ROSSO, S., SALIM, C. A. Pequena Produção e Custos de Reprodução da Força de Trabalho: crítica e hipóteses alternativas. Brasília, UnB, Série Sociológica, n.21, 1980.

DELGADO, G. da C. Pequenos produtores, política agrícola e política agrária. Brasília, IPEA, s.d.

GARCIA JR., A. R. Terra de trabalho: trabalho familiar de pequenos produtores. Rio de Janeiro: Paz e Terra, 1983.

GRAZIANO DA SILVA, J. Estrutura agrária e produção de subsistência na agricultura brasileira. São Paulo, HUCITEC, 1980.

GUIMARÃES, A.P. Quatro Séculos de Latifúndio. R. J.: Paz e Terra, 1968.

KAGEYAMA, A., BERGAMASCO, S. M. P. A estrutura da produção no campo em 1980. Rev. Perspectivas, São Paulo, 12/13: 55-72, 1989/90.

KAGEYAMA, A. A. e SILVA, J. G. da. Tecnologia e Campesinato: o caso brasileiro. Rev. de Economia Política. v.3, n.4, out./dez. 1983 p.21-56.

" "O novo padrão agrícola brasileiro: Do complexo rural aos complexos agroindustriais.”. In.: DELGADO, G. (org.) Agricultura e Políticas Públicas. Série IPEA, n.127, Brasília, IPEA, 1990. pp. 113-223.

KAUTSKY, K. A questão agrária. 3.ed., São Paulo, Proposta Editorial, 1980.

LACERDA, G. N. de. Capitalismo e produção familiar na agricultura brasileira. São Paulo, USP/IPE, 1985.

LAMARCHE, H. (cood.) A agricultura familiar. Campinas. Ed. UNICAMP, 1993. 336p.

LEIDKE, E. R. Capitalismo e Camponeses: relação entre indústria e agricultura na produção de fumo do Rio Grande do Sul. Brasília, UnB, 1977. (Tese de Mestrado). Mimeo.

LEITE, S. P. A pequena produção e o quadro recente da agricultura brasileira. Rev. Perspectivas. S.P., 12/13: 31-53, 1989/90.

LÊNIN, V. I. Capitalismo e Agricultura nos EUA: novos dados sobre as leis de desenvolvimento do capitalismo na agricultura. S.P., Ed. Brasil Debates, 1980

O desenvolvimento do capitalismo na Rússia: o processo de formação do mercado interno para a grande indústria. São Paulo: Abril Cultural, 1992

LOUREIRO, M. R. G. Parceria e capitalismo. Rio de Janeiro, Zahar, 1977 135p. (Biblioteca de Ciências Sociais).

MARTINS, J. S. Capitalismo e Tradicionalismo: Estudo sobre as contradições da sociedade agrária no Brasil. S.P., Pioneira, 1975

O cativeiro da terra. São Paulo, Ciências Humanas, 1979. 157p. (Brasil Ontem e Hoje, 6).

MARX,K.O capital: crítica da economia política. São Paulo: Abril Cultural, Livro 3,1984.

MOREIRA, R. J. Agricultura Familiar e Assentamentos Rurais: Competitividade, tecnologia e integração social. 1995, mimeo.

OLIVEIRA, F. A economia brasileira: crítica à razão dualista. São Paulo, CEBRAP, 1975. (Seleções CEBRAP, 1).

PALMEIRA, M. Latifundium et capitalisme; lecture critique d'un débat 
Université de Paris, Faculté de Lettres de Sciences Humaines, Paris, 1971. 168p.

PINSKY, J. (org.) Capital e trabalho no campo. S.P., HUCITEC, 1977.

PRADO JR, C. A revolução brasileira. 2.ed. São Paulo, Brasiliense, 1966.

RIZZI, A. T. O capital industrial e a subordinação da pequena produção agricola: o complexo avícola no sudoeste paranaense. Curitiba, 1984. Dissertação de Mestrado, mimeo.

ROSA, S. L. C. Os desafios do PRONAF. Reforma Agrária. Revista da ABRA, 2-3 (25), mai-dez/ 1995. pp.185-192.

SANDRONI, P. Questão agrária e campesinato: a funcionalidade da pequena produção mercantil. São Paulo, Polis, 1980.

SANTOS, J. V. T. Colonos do Vinho: estudo sobre a subordinação do trabalho camponês ao capital. São Paulo, HUCITEC, 1979. 182p. (Ciências Sociais; Realidade Social).

SILVA, S. "Formas de acumulação e desenvolvimento do capitalismo no campo". In.: PINSKY, J. (org.) Capital e Trabalho no Campo. São Paulo: HUCITEC, 1977. pp.7-24.

SORJ, B. Estado e Classes Sociais na Agricultura Brasileira. R. J., Zahar, 1980.

POMPERMAYER, M. \& CORADINI, O. Camponeses $e$ agroindústrias: transformação social e representação na avicultura brasileira. R. J., Zahar, 1982.

SOUZA, P. R. Salário e mão-de-obra excedente. In.: Estudos CEBRAP, 25/jan.,1978.

URBANO, F. Exportar é o que Importa, ou o que Importa é Exportar? Avaliação das Políticas do Governo Federal para a Agricultura Familiar Brasileira. Anais do XXXV Congresso Brasileiro de Economia e Sociologia Rural. ago./ 1997. pp.18-37.

VEIGA. J. E. O desenvolvimento agrícola: uma visão histórica. São Paulo: HUCTTEC, 1991.

VELHO, O. G. Capitalismo autoritário e campesinato; um estudo comparativo a partir da fronteira em movimento. São Paulo, DIFEL, 1976. 261p. (Corpo e Alma do Brasil.)

VINHAS, $\vec{M}$. Problemas Agrário-Camponeses do Brasil. Rio de Janeiro: Civilização Brasileira. 1972. 335p.

WANDERLEY, M. N. B. O camponês: um trabalhador para o capital. In: Cadernos de Difusão Tecnológica, vol.2,n.1, jan./abr. 1985. pp. 1378 .

A agricultura familiar no Brasil: um espaço em construção. Reforma Agrária. Revista da ABRA, 2-3 (25), mai-dez/1995. pp.3757. 